\title{
U-Pb Scheelite LA-ICP-MS Dates from the Historic Yellow Pine Pit, Yellow Pine Au-Sb-W Mining Area, Central Idaho, USA
}

\section{October 22, 2017}

\author{
Niki E. Wintzer ${ }^{1,2}$, Virginia S. Gillerman ${ }^{3,4}$, and Mark D. Schmitz ${ }^{4}$ \\ ${ }^{1}$ United States Geological Survey, Spokane, Washington 99201 \\ ${ }^{2}$ School of the Environment, Washington State University, Pullman, Washington 99164 \\ ${ }^{3}$ Idaho Geological Survey, Boise, Idaho 83702 \\ ${ }^{4}$ Department of Geosciences, Boise State University, Boise, Idaho 83725
}




\section{Antimony is Critical}

- A critical mineral commodity is a commodity with a supply chain that is vulnerable to disruption, that serves an essential function in the manufacturing of a product, and the absence of which would cause significant economic or security consequences.

- The United States relies on China for the majority of imported antimony, so the supply is vulnerable to disruption.

- Largest single antimony use is in flame retardants.

- Stibnite $\left(\mathrm{Sb}_{2} \mathrm{~S}_{3}\right)$ is the main ore mineral for antimony $(\mathrm{Sb})$. 


\section{Why Yellow Pine?}

- Most antimony documented in the United States.

- Indicated antimony is over 155 million pounds with an additional 25 million pounds inferred (Huss and others, 2014).

- Indicated gold is over 5 million ounces with an additional 1 million ounces inferred (Huss and others, 2014).

- Pre-feasibility study was completed in 2014 , mine development permit applications have been submitted to state and federal agencies, and a draft of the Environmental Impact Statement is expected in 2018 (Dail, pers. commun., 2017).

- Price of antimony is $\$ 3.76$ per pound as of 10-17-2017 (www.snl.com).

- Price of gold is $\$ 1,283$ per ounce as of 10-17-2017 (www.snl.com).

- The United States is $3^{\text {rd }}$ in the world for active antimony projects, and Yellow Pine makes up over $98 \%$ of US antimony (www.snl.com). 


\section{Ore Deposit Classification}

- Gold-antimony epithermal deposit; that deposit type accounts for $20 \%$ of the world's antimony.

- Ore occurs mostly as disseminated auriferous arsenopyrite and pyrite hosted by granodiorite that is cut by scheelite and stibnite veins.

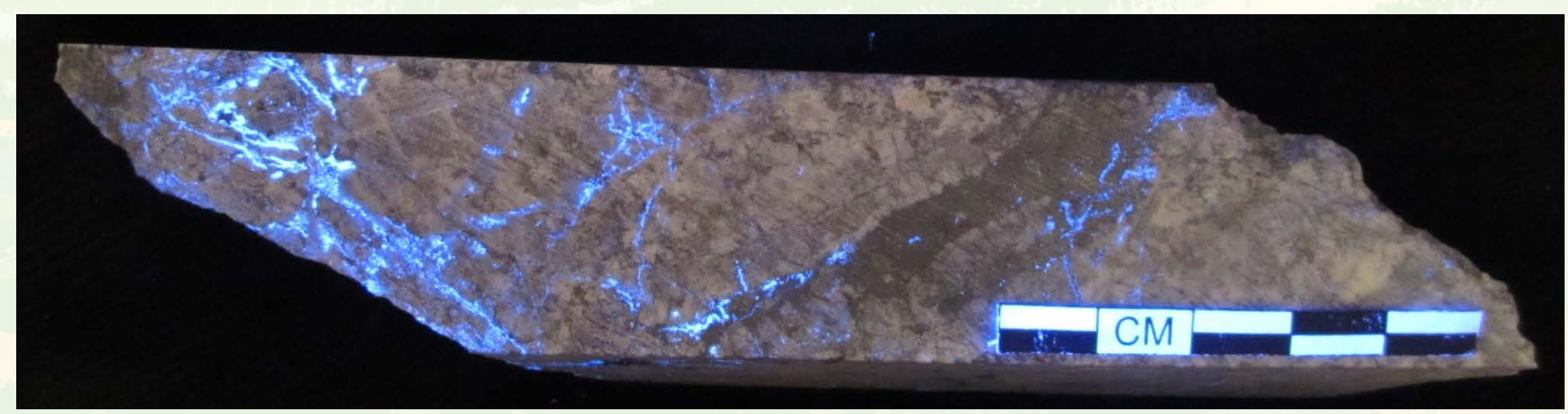

Drill core of granodiorite that hosts disseminated auriferous iron sulfide minerals all of which are cut by scheelite and stibnite veins; scheelite seen as blue fluorescent mineral. Sample access courtesy of Midas Gold Corporation. 


\section{Geology Overview}
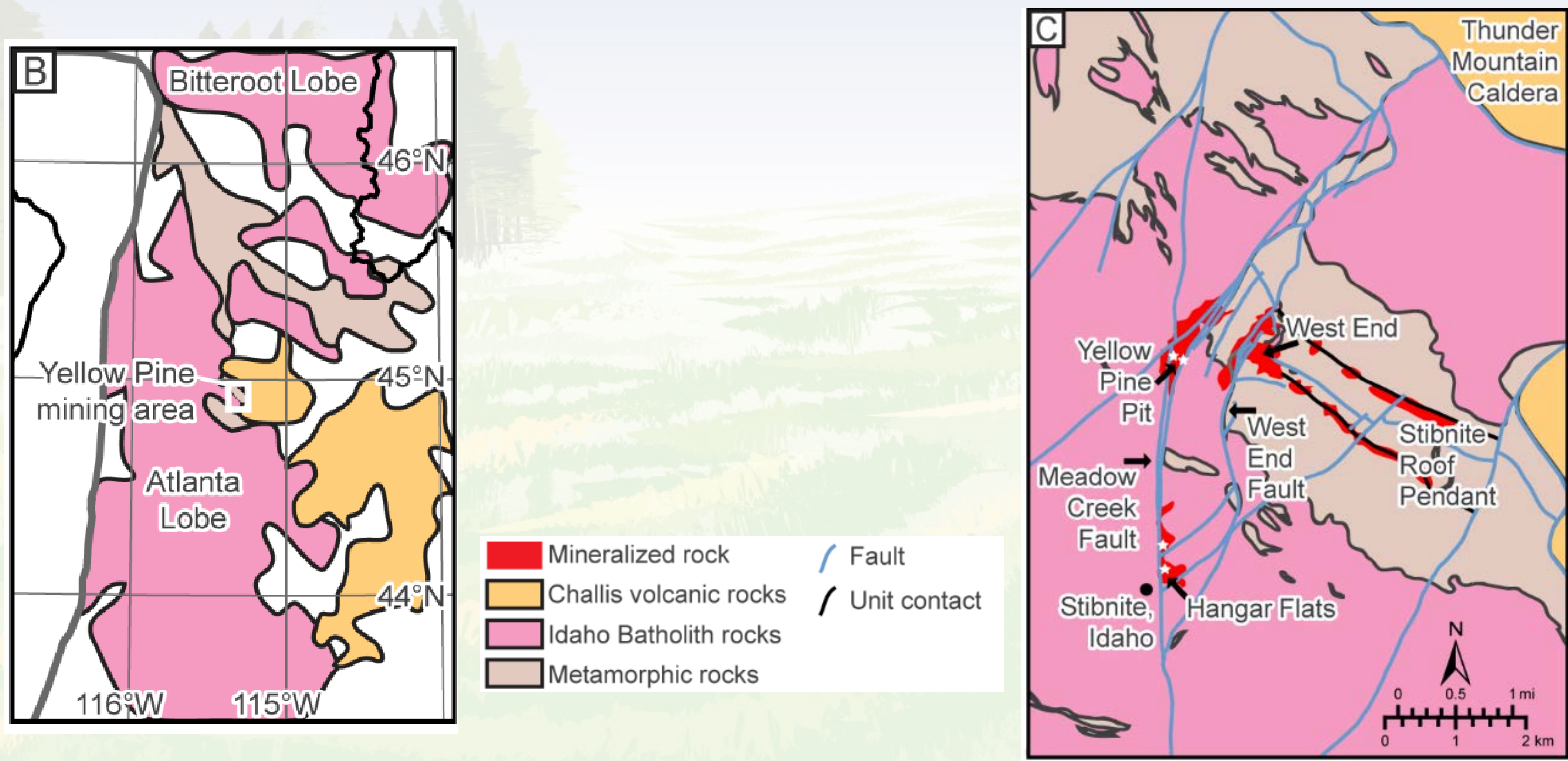


\section{Geologic Timeline Regional and Local to Yellow Pine}

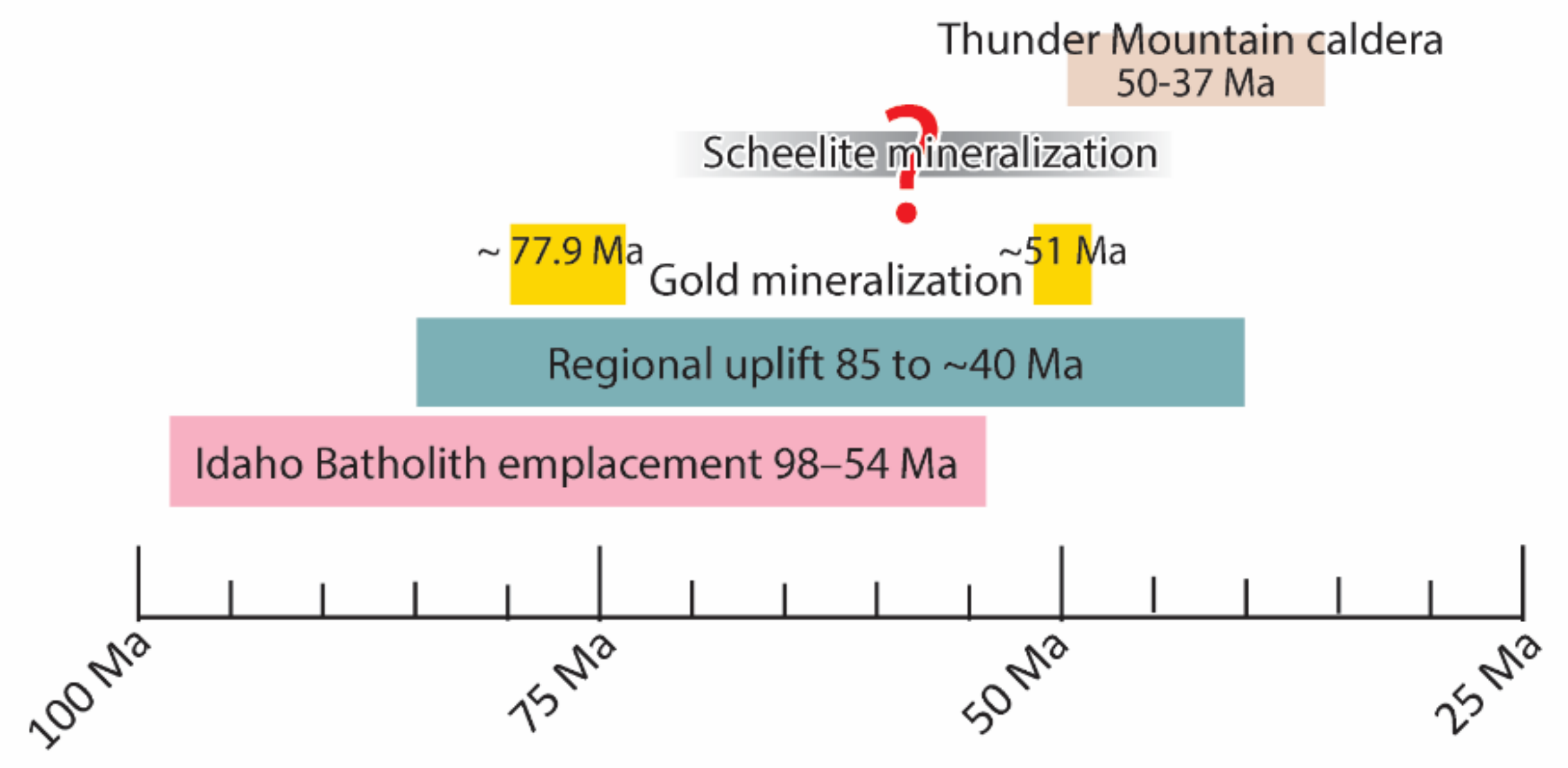


Two most recently obtained dates presented herein are highlighted in yellow

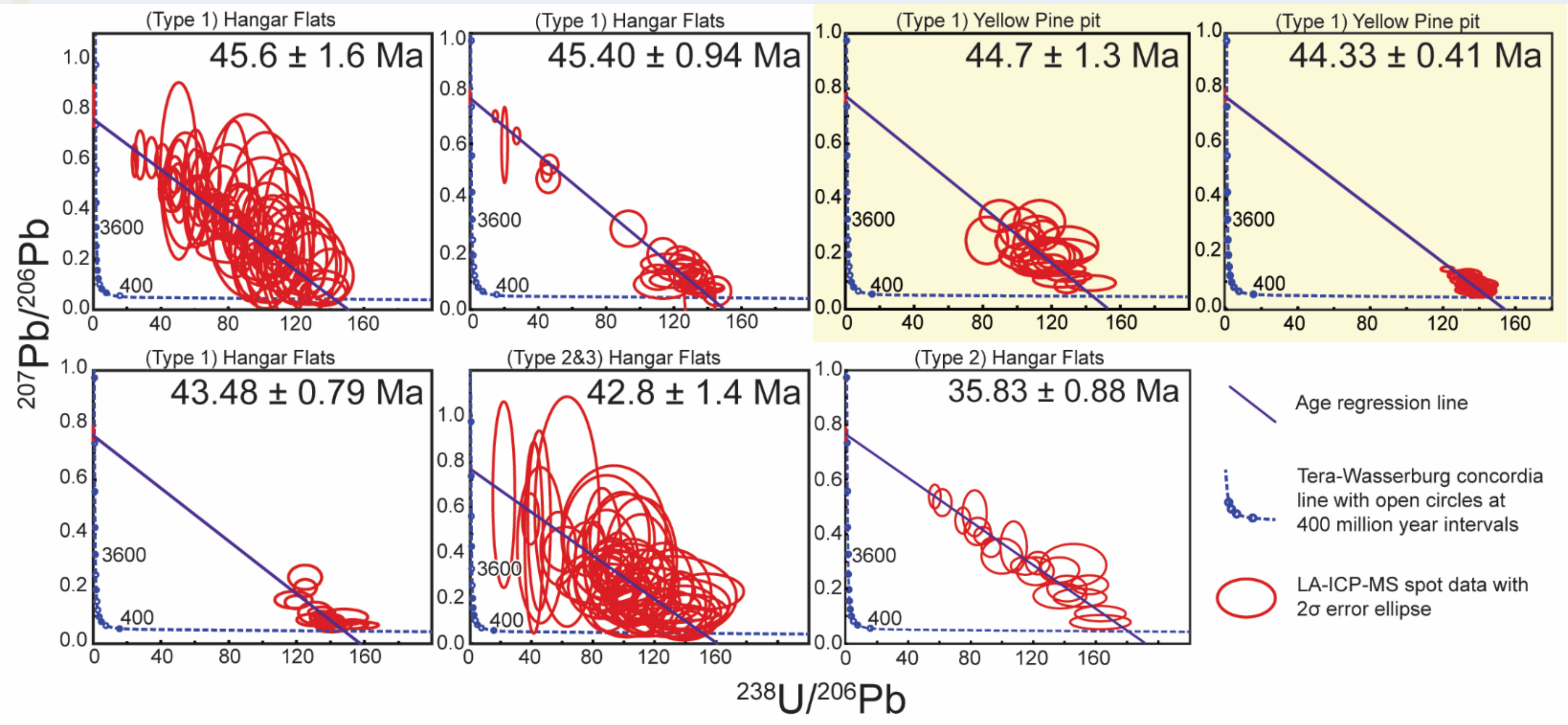




\section{Geologic Timeline Regional and Local to Yellow Pine}

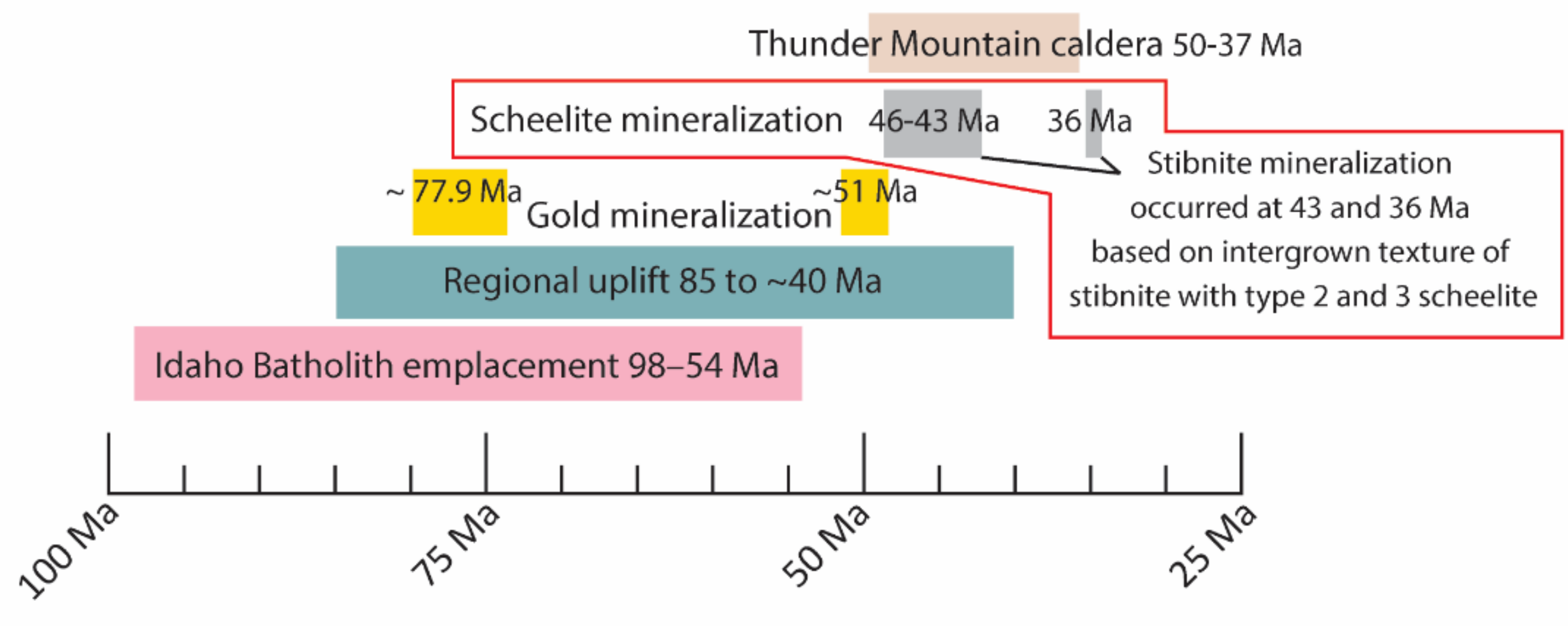




\section{What To Remember}

- U-Pb scheelite geochronology shows Yellow Pine scheelite and stibnite mineralization is Eocene so coeval with the Thunder Mountain Caldera activity. 


\section{Special Thanks}

Dr. Jeff Vervoort - Washington State University

Christopher Dail, Perry Ponshock, Eric Gordon — Midas Gold Corporation

Paul W. Pohwat-Smithsonian Institution National Museum of Natural History

Dr. Peter Vikre - United States Geological Survey

Dr. Marion Lytle-Isotope Geology Laboratory at Boise State University 